Tihomir CIPEK*

\title{
THE POLITICAL VERSUS THE STATE? THE RELEVANCE OF CARL SCHMIT'T'S CONCEPT OF THE POLITICAL
}

\begin{abstract}
The aim of the article is to examine the relationship between the state, democracy and the Carl Schimitt's concept of the political. That is going to be done by reconstructing the concepts of Schmitt's political theory and finding out whether they can be used to explain the ideology of the new right-wing populism and illiberal democracy. As it turns out, the Schmitt's reduction of the political to the friend/enemy antagonism makes the core of the illiberal democracies' ruling narrative. The Schimtt's understanding of the political doesn't defend the state as a political space but by cancelling of the liberal elements of democracy ruins the state institutions. The analysis shows that Schmitt's notion of the political cannot be used to build effective democratic state institutions. Namely, in his definition of the political, politics actually exists only on the outwards, towards some other nation, some other political unity, but not within the state itself.
\end{abstract}

Keywords: state, the political, Carl Schmitt, illiberal democracy

\section{Introduction}

The interest of social sciences is once again centred on the relation between the state and democracy. The discussion has been prompted by the rise of the right-wing populist parties in Europe and the theses on the crisis of democracy. The rise of right-wing populism is explained in two ways. The first approach starts from the socio-economic situation and notes that the ranks of populist protest parties are being swelled by the economic losers of globalisation and transition. The second approach takes culture and national identity as its starting point, and believes that right-wing populists are supported by extremely conservative voters who feel like they need to defend their religion and nation, which are in danger. Both approaches contain some elements of truth, but the countries where right-wing populism

* Tihomir Cipek, PhD, Professor, Faculty of Political Sciences, University of Zagreb, Croatia. DOI: $10.51936 /$ tip. $58.2 .268-283$ 
first appeared are still welfare states (France, Austria, the Netherlands), while conflicts in the interpretation of cultural values occur only when the hard right comes to power and starts changing gender policy, as can be seen on the example of Poland (Manow, 2020). Of course, there were also the 2010 Eurozone crisis and the 2015 refugee crisis. All of these interpretations contain some truth, but the main reason for the rise of right-wing populist parties seems to be of a structural nature. This is about the political elites' avoidance of making decisions, of intervening in the sphere of economy with the levers of political power, and at the same time, about neglecting democracy and the state (Streeck and Schäfer, 2013). Citizens demand that politics, or rather the state, protect them, while political elites claim that the market will do that on its own. Thus, the reason for the contemporary crisis of democracy and the emergence of right-wing populism lies in neglecting the functions of politics and the state (Böckenfoerde, 1988; Mouffe, 2004; Brown, 2015, 2019; Streeck, 2020). The functions of the state are taken over by international arbiters of power, which are not democratically elected and are not subject to democratic control, such as the World Bank, the International Monetary Fund, and various expert commissions and courts. At the same time, the neoliberal ideology claims that the state is something bad because it prevents the free operation of the market. The argument is that politics is an unnecessary obstacle to the economy and that the state should be reduced to a minimum, because everything will be resolved by the market (Brown, 2019; Rizman, 2020; Cayla, 2021). On the other hand, it is quite clear that democracy is historically and institutionally tied to the state (Dharendorf, 2002; Streeck, 2020). We thus find ourselves in a paradoxical situation, in which the political is at the level of the state, but public policies are at a supranational level, or rather at the level of the EU. Essentially, we are talking about a process of depoliticization (Mounk, 2018). This text starts from the thesis that neoliberal ideology puts the interests of corporations before the interests of nation states, and that right-wing populism responds to this process of depoliticization by promising to return the state and democracy to the people. This promise of a return of politics has prompted a discussion of Carl Schmitt's political theory and his understanding of the political (Balakrishnan, 2000; Müller, 2003; Mouffe, 1999, 2013; Petersen, 2018). This poses the question whether is it possible by the means of Carl Schmitt's concept of the political to hold back the depoliticization, to enhance the dynamics in the political field, that is crucial for the state institutions, and thus strengthen the state as the true space of democracy. This question is going to be faced by the method of qualitative analysis of the discourse (Jørgensen and Philips, 2002). The starting thesis will be that the central purpose of political theory's concepts is to serve the political struggle and to develop the hegemonic model of the interpretation of political phenomena. 


\section{The Crises of the State?}

The understanding and the concept of the state is one of the most important phenomena in political science. In its inception, political science developed as and was called the science of the state. Today, mainstream public discourse is dominated by the thesis that the state is unnecessary, that it has allegedly been transcended, that it should be reduced to the minimum (Brown, 2015, 2019; Cayla, 2020). This is actually a ubiquitous media dissemination of the central thesis of neoliberal ideology, which claims that everything would be great if all interpersonal relations were reduced to market relations. ${ }^{1}$ More pointedly, it could be said that neoliberals and US neoconservatives claim that the state is nothing, while the market is everything (Stiglitz, 2019; Risman, 2020; Streeck, 2021). To be sure, both of these groups hold this principle to be true only until it is failed private banks that need to be bailed out by the state (Hall, 2015). This contempt toward the state has troubling, twofold consequences. The first consequence is for the liberal democracy itself. Namely, as stated by the classic of liberal political theory Ralf Dahrendorf (2002), democratic political order was historically and institutionally designed for nation states, which is why democracy depends on

270 the efficiency of state institutions. The second point is connected to the acceptance of the idea of the social state. The idea of the social state rested on the agreement between people's and social-democratic parties that was achieved after the Second World War. The social state was the West's effective answer to the ideological challenges coming from the Soviet Union. The collapse of the Soviet Union and the communist dictatorships that began in 1989 marked the beginning of the degradation of the social state of the European West. By questioning the significance of politics, the dominant media discourse also questioned the state itself in its political and economic function.

Thus the predominance of the ideology that celebrated the market and the necessary dominance of financial capital institutions over politics also wreaked havoc on the power of the state (Robison, 2006). It seemed like the state was good for nothing except listening to the dictates of banks and other institutions of financial capital. A classic idea of Hegel's political philosophy, which was based on the division between the state and society and advocated for the supremacy of the state, seemed to become obsolete. The same could be said for the theoretical premises of Max Weber, as well as many other right- and left-wing thinkers who advocated for the idea of a strong, effective state. In this sense, it is interesting that the neoliberal devaluation

1 The way in which the Slovenian media turns essential political phenomena into non-political ones is demonstrated by Pikalo and Trdina (2011). 
of the state did not lead to the actualization of Weber's or Hegel's theory of the state, but rather put a spotlight on the political theory of Carl Schmitt, a Nazi law theorist. Schmitt has become the favourite theoretician of the radical and extreme right. What is especially popular is his concept of the political, which reduces politics to the friend-enemy relation. That is why I will use Schmitt's theories to explain the contemporary arguments about the state. I will first point to the perception of Schmitt's political deliberations. Secondly, I will try to reconstruct Schmitt's notion of the political and his interpretation of the relation between the liberal and the democratic elements of the political order. Finally, I will show how the discourse of the new "conservative revolutionaries", who pride themselves on establishing "illiberal democracy", understands the political, the state and democracy.

\section{The Perception of Schmitt's Theory}

Today, Schmitt's political theory is the topic of discussion on both ideological poles, the left and the right. This is true despite the fact that Schmitt was a Nazi, and thus completely compromised as a person who was unable to distinguish right from wrong. Schmitt was accepted in the National Socialist German Workers' Party (NSDAP) on the $1^{\text {st }}$ May 1933, the same day as Martin Heidegger, and was banned from university work after the War. Specifically, in his texts published in the legal journals of the Third Reich, Schmitt provided justification for the Nazi totalitarian dictatorship. After the War and the victory of the anti-fascist coalition, he did not renounce his writings that legitimised Nazism, and stayed silent on Nazi crimes and the Holocaust (Mehring, 2017: 123).

In spite of this, his attack on liberalism seemed useful to the French left, which brought his theory back into discussion. In this sense, I would single out Chantal Mouffe $(1999,2013)$, whose theory of agonistic democracy was based on Schmitt's friend-enemy dichotomy. This allowed her to use the rehabilitation of the political to advocate for a radical change of the socioeconomic order. She liked Schmitt's protest against the disappearance of the political as well as his strong rejection of liberalism. In her theory of democracy, Chantal Mouffe tries to mitigate Schmitt's attack on liberal democracy by replacing his term "enemy" with the word "adversary". Today, Mouffe (2018) is a decisive proponent of the concept of left populism. She wants to preserve the political, and use this concept to challenge the current capitalist socio-economic order. In a word, in contrast to the liberal attempt to neutralise the political, the French left used the theory of Carl Schmitt to revitalise this concept in its theoretical discourse and thus maintain the possibility of changing the economic and political order.

Tendrils of Schmitt's theory can also be found in the writing of the 
hermeneutists Paul Ricoeur. In his theory, he also differentiated between le politique - the political, and la politique - politics, thus trying to preserve authenticity, or rather prevent the latter from compromising the former. The introduction of the notion of the political in the discussion is meant to heighten the tensions in the political and economic order, and thus preserve the possibility of change.

On the other hand, the radical right considers Carl Schmitt to be a cult author, alongside Ernst Jürgen (Maus, 1980; Müller, 2003; Weiß, 2017). His notion of the political, attack on liberalism and parliamentarism (Holmes, 1993), and especially his linking of nationalism and statism are key battle cries of the meta-politics of the new European right (Weiß, 2017; Salzborn, 2017). ${ }^{2}$ German radical right magazines - "Junge Freiheit", "Sezession" often discuss his ideas. And the leading ideologist of the new French right Alain de Benoist $(2003,2010)$ uses Schmitt's political ideas as a theoretical foundation for right-wing cultural revolution. Armin Mohler, whose book "Die Konservative Revolution in Deutschland 1918-1932" (1950) brought the nationalist theses of the Weimer Republic's conservative revolutionaries back into public life, did not hide his admiration for Carl Schmitt and his political theory. Schmitt's ideas are also propagated by the extreme right 272 wing of the AfD, gathered around Björn Höcke and Götz Kubitschek and his Institute for State Policy (Weiß, 2017: 48). Namely, the main enemy of the new extreme right is liberalism. At the centre of their ideology is Schmitt's notion of the political, founded on the friend-enemy relation. The idea of the political, as well as Schmitt's linking of nationalism and statism, form the basis of illiberal democracies that are taking form in Hungary and Poland. These countries are trying to suspend liberal principles of the development and protection of individual, as well as minority rights. The ruling elites claim - following Carl Schmitt's teaching - that the state is a reflection of the spirit, and the form of the body of a nation. On the other hand, Schmitt considers the political to be superordinate to the state (Mehring, 2011; Balakrishnan, 2000; Holmes, 1993; Posavec, 1989). The issue thus lies in the fact that Schmitt's theory juxtaposes the political and the state. This opposition is especially strong if one understands the state as an array of institutions based on liberal-democratic principles. ${ }^{3}$ However, this contradiction goes unnoticed by the extreme and radical right, which focuses on the conflict between the liberal and the democratic principles of the political order.

2 In this text, I tried to reveal the political-instrumental usage of Carl Schmitt's political and legal theory. His influence on numerous political theoreticians who partly accepted, but also critiqued his theory, was covered by Reinhard Mehring. In this sense, he listed Schmitt's students such as Werner Becker, Otto Kirchemer, Ernst Forsthoff etc. (Mehring, 2017: 115-121).

3 An interesting interpretation of Schmitt as a thinker who shares the liberals'fear of the people is given by Mastnak (2015: 96-132). 
But before I try to explain, I will attempt to reconstruct Schmitt's notion of the political.

\section{The Political}

Schmitt considered "Der Begriff des Politischen" (Mehring, 2011: 146) to be his best work. The book appeared in three editions - 1927, 1932 and 1933 - with no major differences between them. The most commonly read and subsequently reprinted is the 1932 edition (Ottman, 2010: 241). The thinking is that this edition has not been opportunistically adjusted to Nazism and, more importantly, that it highlights the intensity of a social relation that only becomes a political relation through the degree of its intensity, which is important for the interpretation of the political. Schmitt's theses on the concept of the political bring a completely new understanding of politics. Until then, politics was seen as a phenomenon that was essentially tied to the state. The state was the political, it had political monopoly. This was implicitly understood in the political theory of the $19^{\text {th }}$ and early $20^{\text {th }}$ century, as is observed by Henning Ottmann (2010). The state was on one side, and the society on the other, "here politics, there culture; here the internal, there the external". And further: "War and peace, military and civilian, neutral and non-neutral were separate. The introduction of the notion of the "political' meant that those clear divisions no longer exist" (Ottmann, 2010: 242). The political was defined by Schmitt as a friend - enemy relation. "In contrast to the various relatively independent endeavours of human thought and action, particularly the moral, aesthetic, and economic, the political has its own criteria which express themselves in a characteristic way... Let us assume that in the realm of morality the final distinctions are between good and evil, in aesthetics beautiful and ugly, in economics profitable and unprofitable" (Schmitt, 1932: 13-14). "The specific political distinction to which political actions and motives can be reduced is that between friend and enemy" (Schmitt, 1932: 14). It should be emphasised that Schmitt does not use adjectives "friendly" - "antagonistic", but precisely nouns "friend"

- "enemy". Hence, this is a subject that can be either a friend or an enemy. Schmitt focuses his attention on the enemy. In his theory, the enemy is more important that the friend. Namely, he thinks that it is only with regard to the enemy that a nation can be formed as a homogeneous unit. This raises the question: who is the enemy? Is the enemy an existential category? These are the question that I will try to answer by reconstructing key parts of Schmitt's theory.

It can be said that Schmitt formulated his notion of the political by rehabilitating Hobbes' concept of a natural condition. Hobbes claims that the natural condition is a state of war. According to Schmitt's interpretation, the 
political is really the natural state. But while Hobbes thinks that the natural state - as the state of war between individuals - should be abandoned, Carl Schmitt on the contrary approves the political, based on the friend-enemy relation, as the natural state. His opinion is that the moral or the normative in liberalism cannot exclude the political (Schmitt, 1932: 15-16). The enemy is simply the Other, and not just any Other, but a Stranger. The enemy is never a private adversary, he is always a public enemy (Schmitt, 1932: 16). Moreover, he is designated as a Stranger, meaning the Enemy, by his very existence. "The political enemy need not be morally evil or aesthetically ugly; he need not appear as an economic competitor, and it may even be advantageous to engage with him in business transactions. But he is, nevertheless, the other, the stranger; and it is sufficient for his nature that he is, in a specially intense way, existentially something different and alien, so that in the extreme case conflicts with him are possible" (Schmitt, 1932: 16). For Schmitt, a "real enemy" is the one who threatens the existence. Politics is the struggle over "to be or not to be" (Ottmann, 2010: 245). It follows that the political cannot be prevented or diluted by formalism, legal provisions. For Schmitt, the return to the political signifies the abandonment of the status $q u o$, guaranteed by the liberal rule of law. The political is present in particularly important cases of the state of emergency, when a particular order is in danger. The threat to the system can come from many directions. A system can be jeopardised by civil war, outside attack, terrorism. Such situations show that the "sovereign is he who decides on the exception" (Schmitt, 1922: 13). The state of emergency highlights the fact that only the state has the monopoly over legitimate force. The state cannot be broken down into a series of civil society organisations, unions, churches - what we would now call non-governmental organisations. To wit, none of these institutions have the power of the state. Only the state wields the amount of power that can make a decision on war and peace. Within its borders, the state assures peace, while outwardly it can wage war (Schmitt, 1932: 38). "The justification of war does not reside in its being fought for ideals or norms of justice, but in its being fought against a real enemy" (Schmitt, 1932: 38). Interestingly, Schmitt considers politicians to be better schooled for battle than soldiers because, unlike soldiers who only fight occasionally, politicians fight constantly for as long as they are in politics (Schmitt, 1932: 22).

The state as a system of legal norms thus tries to supress the political, but it cannot destroy it. The point of its existence is to decide who is the friend and who the enemy and, as a last resort, to lead the war against the enemy (Schmitt, 1932: 38). The concept of the political thus has a double meaning; it is as if Schmitt cannot conclusively make up his mind. On one hand, "the political assumes the place of the state”. „On the other hand, Schmitt does not support the diagnosis of the total dissolution of a sovereign state" 
(Ottmann, 2010: 245). For Schmitt, the state is always and solely a nation state. The state and the nation are strongly connected, and no global, universal state is possible, claims Schmitt (1932: 42-47). He corroborates this thesis with history, and claims that there never was a world state, only empires, and that - despite their ambition of constant expansion - no empire ever encompassed the entire world. A world state, thinks Schmitt, would actually be the state of the entire human kind (Schmitt, 1932: 42). This would mean the total destruction of the political, of the friend-enemy relation. Namely, humanity as such, holds Schmitt, has no enemy (Schmitt, 1932: 42). "A world state would therefore be apolitical, an enormous consumer and production community, some kind of a global super-market, but not a state" (Ottmann, 2010: 247). Schmitt's thesis that humanity does not have an enemy is wrong. It is namely clear that humanity can be its own enemy. Civil war between humanity has not been precluded. But Schmitt never abandoned faith in his definition of the political and the strength of nationalism, which is why he did not believe that a world state of human kind was possible. Anyway, such a state would today probably be understood as a product of market globalisation, meaning a political result of economic liberalism. And, in Schmitt's eyes, it was precisely liberalism that was the enemy.

\section{Anti-liberalism}

Schmitt scathingly wielded his political theory against two opponents liberalism and Soviet communism. He directed his efforts at what he thought was the weaker opponent, and that was liberalism. In his opinion, liberalism is trying to destroy what is important - the political. Liberalism wants to take the conflict, struggle, decision-making and the state, and replace them with economy and ethics (Schmitt, 1932: 15). Through its moralising, which is embodied in the philosophy of human rights, liberalism wants to supress the political. "The negation of the political, which is inherent in every consistent individualism, leads necessarily to a political practice of distrust toward all conceivable political forces and forms of state and government, but never produces on its own a positive theory of state, government, and politics" (Schmitt, 1932: 56). Schmitt argues that liberalism is trying to dissolve the political into morality or the market, because political liberalism does not have a content of its own. It transforms conflict into discussion, constantly invokes morality, and ignores the clash of real powers. It tries to turn every conflict into a competitive bidding on the market. Liberalism runs from the decisions on war or peace that are crucial for the political. Instead, it fools itself by discussion dynamics in spiritual matters, and by the principle of competition in economic matters (Schmitt, 1932: 58). Neither the first, nor the second principle cannot substitute the political as a friend-enemy 
relation. This relation can only be ended by a proclamation of war, and this right to decide on matters of life and death is under the purview of the state (Schmitt, 1932: 33-34). The state was defined by Schmitt as a homogeneous unity of a nation. In his theory, the nation is not a collective of citizens who abide by the constitution and laws they adopted themselves, but a community of descent. It is precisely this thesis that makes Schmitt so popular with the new right and right-wing extremists. Namely, the extreme and radical right bases its politics on integral nationalism. The state is a reflection and the body of a unique, ethnically-based nation. This is also one of the key thesis of the ideology of the so-called illiberal democracy. Liberal understanding of the state - which restricts the power of the state through the tripartite division of power, the protection of civil and human rights, investigating journalism and independent media - is completely inacceptable to proponents of this ideology. That is why they like Schmitt's critique of liberalism so much: to recap, Schmitt claims that, although liberalism did not "deny the state", it has "neither advanced a positive theory of state nor on its own discovered how to reform the state, but has attempted only to tie the political to the ethical and to subjugate it to economics. It has produced a doctrine of the separation and balance of powers, i.e., a system of checks and controls 276 of state and government. This cannot be characterized as either a theory of state or a basic political principle" (Schmitt, 1932: 49).

Not only does Schmitt deny liberalism's ability to form the theory of the state, but he proclaims it an anti-national ideology. Namely, in his theory, the state is the supreme expression of a people's existence. It allows them to determine their own identity. The ultimate consequence of the political is actually a matter of the state, because the state is that body of the people that decides on matters of war and peace. And though Schmitt does not think that the political can be reduced to the state, it is still connected to it. Liberal teaching on parliamentarism and the tripartite separation of power restricts the power of the state in its effort to establish a purely moral or purely economic state. And this - emphasises Schmitt - is not possible. The political is unavoidable, and the friend-enemy relation is always established. Political decisions on who constitutes the enemy are necessary. The political is that which makes people - a people. "If a people no longer possesses the energy or the will to maintain itself in the sphere of politics, the latter will not thereby vanish from the world. Only a weak people will disappear" (Schmitt, 1932: 41). Conflict and nationalism are thus important elements of Schmitt's political theory. The point is that Schmitt develops the idea of a homogenous people, defined by their ethnic origins (Salzborn, 2017: 66). In its essence, the state is the body of a nation that has been defined in this way. These ideas are exactly the reason why Schmitt has been enthusiastically embraced by the ideologues of the new right and the illiberal democracy. 


\section{Illiberal Democracy and the State}

It seems that illiberal democracy, both as an idea and a system, emerged primarily as a reaction to neoliberalism. Namely, neoliberalism is also an ideology. It is an ideology that tries to reduce all interpersonal relations to market relations. Such reduction is, of course, not possible; people are not determined only by their interests, but also by their identities (Fukuyama, 2018). ${ }^{4}$ Politics does not exist just to create a safe operating space for big businesses and financial capital, but also to watch out for the interests of people its represents. However, emboldened by the fall of the Berlin Wall and the collapse of real socialism and the communist dictatorships, Western elites concluded that the liberal ideology of market absolutization was the ideology of the future. That is why neoliberal ideology was wholeheartedly accepted by both right- and left-centre parties. The claim was that the state had lost all its functions, that the concern for citizens should be assumed by the invisible hand of the market, and that democracy in a nation state should be replaced by global democracy. In short, it was claimed that the market was everything, that those more capable and stronger always win, and that the rights of individuals were everything while the community was nothing. These theses of neoliberalism were advocated by the global class (Darendorf, 2002; Tooze, 2018).

The rule of the global class created a new inequality and thus endangered the functioning of the institutions of the nation state. Thus, while citizens were asking for the state's protection, mainstream politicians referred them to the market, explaining that it would solve all their problems. People's parties, but also social-democrats who followed the "third way" showed people that, though it was possible to choose - countries did have parliamentary elections - a real choice did not exist. It turned out that policy was on the level of the EU, while politics remained at the level of nation states. Politicians of the conservative nationalist right, first in Hungary and then in Poland, promised to change that - to stand up to the EU and capacitate the state to start taking care of the nation. Viktor Orbán's government thus introduced a tax on big (foreign) business and financial capital, and saved Hungarian families who had loans in Swiss francs with interest rates that kept increasing so much that, after many years of paying back the loans, they would still owe more to the banks than what they initially took out. This agony was decisively halted. The state abolished loans in Swiss francs, and all liabilities were converted to the Hungarian currency, the forint. These measures, which curtailed the tyranny of the banks, helped Orbán achieve a

4 The basic thesis of liberalism, which states that people can always recognise their best interest, is probingly questioned by Lukšić (Lukšić, 2002). 
widespread popularity. His propagandistic formula - Us (Hungarians) and Them (foreign bankers) - proved to be effective. It allowed him to position himself, and not always falsely, as the protector of the "little" Hungarian people. Liberalism was proclaimed to be the real adversary of the people; moreover, Orbán claimed that there would be no true democracy until liberalism was rejected. He started to talk about how Hungary was establishing a system of "illiberal democracy" (Orbán, 2014), and this formula became attractive to other national conservatives and radical right-wingers.

In their rejection of liberalism, illiberal democrats seem to follow the ideas of Carl Schmitt. First of all, there is the idea of the political that reduces it to the friend-enemy relation. Secondly, the idea that liberal and democratic elements of the political order are in an irreconcilable conflict. According to this idea, liberal principles of the protection of individual and human rights are in conflict with the democratic principle of the rule of the majority. The third idea concerned the state as a body of an ethnically-defined nation; the state was understood as an instrument of integral nationalism. All three ideas form the foundation of the ideology of the ruling elites that support the illiberal democracy. Based on these ideas, liberalism is proclaimed to be the main cause for the collapse of the nation. The radical right claims that liberal principles of the equality of women, gender equality, the right to a same-sex marriage, actually supress the will of the people, meaning democracy (Cipek and Lacković, 2019: 168-170). Radically-right discourse emphasises the polarity of liberal and democratic elements of the political order. Furthermore, it is claimed that illiberal democracy is actually real democracy, and that it is only with the advent of this type of democracy that the true will of the people will be heard. Namely, the gist of the radical-right position lies in the claim that it is the only one that represents the people. And the will of the people, or rather democracy, is contrasted by Schmitt and illiberal democrats to the legal state.

But, are they not still dependent on each other? If a democracy turns into a sphere of identity and the homogeneity of the people, general will becomes an instance that is easy to shape. The people thus become everything, and the rule of law as a form of democracy becomes secondary. It seems that the rise of the radical right allowed the neoliberal neglect of the state and politics, but that does not mean that liberal and democratic principles are necessarily opposed. On the contrary, every political order is necessarily based on the liberal principle of moral equality of all people.

\section{Liberal Foundations and Democratic States}

It is indisputable that liberal and democratic elements of contemporary political order can differ one from another. On the one hand, there is the 
liberal principle of individual rights and autonomy, and on the other, the democratic principle of the right of the people to express their will and to rule (Vodovnik, 2017). However, according to Carl Schmitt's theory and the theses of the radical right, liberal and democratic principles are necessarily opposed. For instance, this means that, when the will of the majority is opposed to the will and rights of minorities, the rights of minorities should be subjugated to the will of the majority. Liberal principles should thus yield before democratic principles. But, is it not the fact that democracy without its liberal foundation is actually impossible? In the critique of Schmitt's strict separation of liberalism and democracy, I start from the thesis that the democratic order rests on the idea of moral equality of all men. In this sense, Schmitt's attack on liberalism is completely misdirected. The basic principle of the democratic order is that all citizens should be treated the same, or rather that the rule of law is applied to everyone equally. Furthermore, in their essence, laws must respect the liberal principle of moral and legal equality of all individuals. Democracy as the rule of majority is based on the principle of civic equality within a state. Individual rights are thus an inseparable part of democracy. The majority has an obligation to respect the rights of the minority. Specifically, it should be emphasised that the minority is also a part of the people. "The majority cannot wield a moral authority that would exceed the power of the people in its entirety. The people do not have the jurisdiction to adopt laws that infringe on individual rights, such authority cannot be assumed even by the majority" (Kis, 2019: 82). Human and civil rights based on liberal principles are therefore the foundation of the democratic order. The rule of the majority cannot be equated with the rule of the entire people, because people as a whole are not homogeneous, but divided into a number of different groups - based on gender, nationality, political affiliation, etc. And every social group deserves the same treatment by the legal state. The state, or more precisely state institutions, have a task to assure a just and equal treatment of all its citizens before the law, and that task, once again, stems from the liberal principle of moral equality of citizens. On the other hand, the state needs to develop mechanisms that would guarantee the realisation of the democratic principle of majority rule. Liberal and democratic principles supplement each other, exist in a dialectic connection, and form the basis for establishing balance through democratic political processes. Hence, they are not opposed, but connected.

\section{Conclusion}

This text starts from the assumption that politics and political activity enable the free existence of man. Choosing the political means choosing the process of decision-making, choosing an option. This shows that there is a 
relative autonomy of the political, because it cannot be reduced to economic tensions in society. The political cannot be reduced to interests coming from the economy, but also cannot escape the dangers that political power can bring. Hence the state is not just an apparatus or an institutional structure, but a social field of power. Similarly, statehood is the terrain that connects social and cultural contexts. That is why Schmitt was right in showing that the political cannot be dissolved in the law, which makes his theory suitable for attacking liberalism both from the left and the right. From the left, it is used by Chantal Mouffe who bases her theory of agonistic democracy on Schmitt's friend-enemy dichotomy. In her theory, she strongly defends the political, although she has replaced Schmitt's notion of the "enemy" with the notion of the "adversary". In this way, she wants to revive democracy as a discussion and conflict over the fundamental features of the capitalist order. On the other hand, right-wing populists also accept Schmitt's thesis that the political cannot be dissolved in the law. But the right does not have an issue with capitalism, and believes that capitalists can somehow be forced to serve the nation. To this end, the thinkers of the new right have affirmed Carl Schmitt's theory of the political. Although the neoliberal neglect of politics and the state has enabled the rise of right-wing populists in Hungary and Poland, this does not mean that liberal and democratic principles are necessarily opposed. Namely, the liberal principle of individual rights is the foundation of the order of democratic states. It is therefore obvious that, in its attempt to revive the political, right-wing populism is destroying the purpose of democratic politics, which is to reach a compromise between opposing interests and different cultural values. Hence, Schmitt's notion of the political cannot be used to build effective democratic state institutions. In his definition of the political, politics actually exists only on the outwards, towards some other nation, some other political unity, but not within the state itself.

Finally, it should be noted that the state is proving to be the only effective entity in which democracy has a chance to function. The state is also the only entity that can effectively oppose economic chaos. Analysis has shown that the state and politics are autonomous areas of human activity, which means that democracy's chances are still good. Any kind of liberation of the individual and the market from the evil state, as advocated by neoliberalism, can bring nothing but the collapse of liberal democracy and the rise of rightwing populism. Therefore, I believe that we need to raise awareness of the importance of the state as a true space of democracy, and thus also affirm the autonomous space of politics. Namely, it is politics - and not the political as defined by Schmitt - that is the only known space of human freedom. 


\section{BIBLIOGRAPHY}

Adam, Armin (1992): Rekonstruktion des Politischen. Carl Schmitt und die Krise der Staatlichkeit 1912-1933. Weinheim: Acta humaniora.

Balke, Friedrich (1996): Der Staat nach seinem Ende. Die Versuchung Carl Schmitts. München: Wilhem Fink.

Balakrishnan, Gopal (2000): The Enemy, Verso, London/New York.

Baume, Sandrine (2009): On political theology: A controversy between Hans Kelsen and Carl Schmitt. History of European Ideas (35): 369-381.

Benoist, Alain de (2003): Carl Schmitt. Bibliographie seiner Schriften und Korrespondenzen. Berlin: Akademie Verlag.

Benoist, Alain de (2010): Carl Schmitt. Internationale Bibliographie der Primär- und Sekundärliteratur. Graz: Ares-Verlag.

Böckenförde, Ernst-Wolfgang (1988): Der Begriff des Politischen als Schlüssel zum statsrechtlichen Werk Carl Schmitts. V: Helmut Quaritsch (ur.). Complexio Oppositorum. Über Carl Schmitt. Berlin: Duncker \& Humboldt, 283-299.

Brown, Wendy (2019): In the Ruins of Neoliberalism. The Rise of Antidemocratic Politics in the West. Publisher: Columbia University Press.

Brown, Wendy (2015): Undoing Democracy. Neoliberalism's Remaking of State and Subject. New York: Zone.

Cayla, David (2020): Populism and Neoliberalism. London, New York: Routledge.

Cipek, Tihomir and Stjepan Lacković (2019): Civil Society and the Rise of the Radical Right in Poland. Politička misao. Croatian Political Science Review 56 (3-4): 153-176.

Dahrendorf, Ralf (2000): Die globale Klasse und die neue Ungleichheit. Merkur (54): 1057-1068.

Dahrendorf, Ralf (2002): Die Krisen der Demokratie: Ein Gespräch mit Antonio Polito. München: C. H. Beck.

Fukuyama, Francis (2018): Identity. The Demand for Dignity and the Politics of Resentment, New York: Farrar, Straus and Giroux.

Jørgensen, Marianne and Louise Philips (2002): Discours Analysis as Theory and Method. London: SAGE.

Kalyvas, Andreas (2008): Democracy and the Politics of the Extraordinary. Max Weber, Carl Schmitt, and Hannah Arendt. Cambridge: Cambridge University Press.

Kis, Janos (2019): Das Rätselder „illiberalen Demokratie“ und was es uns über unseren Begriffder liberalen Demokratie verrät. In: Ludger Hagedorn, Hasewend, Katharina and Shalina Randeria (ed.), Wenn Demokratien demokratisch untergehen: 73-94. Wien: Passagen Verlag.

Lukšić, Igor (2002): Interes : konceptualizacija pojmov. Teorija in praksa 39 (4): 509-522.

Maus, Ingeborg (1980): Bürgerliche Rechtstheorie und Faschismus: Zur sozialen Funktion und aktuellen Wirkung der Theorie Carl Schmitts. München: Wilhelm Fink.

Manow, Philip (2020): (Ent-)Demokratisierung der Demokratie. Berlin: Suhrkamp. Mastnak, Tomaž (2015): Liberalizem, fašizem, neoliberalizem. Ljubljana: Založ$\mathrm{ba} /{ }^{*} \mathrm{cf}$. 
Meier, Heinrich (1995): Carl Schmitt and Leo Strauss. The Hidden Dialogue. Chicago: University of Chicago Press.

Mehring, Reinhard (2011): Carl Schmitt zur Einführung. 5. vollst. überarb. Aufl. Hamburg: Junius Verlag.

Mohler, Armin (1950): Die konservative Revolution in Deutschland 1918-1932: Grundriss ihrer Weltanschauungen. Stuttgart: Friedrich VorwerkVerlag.

Mouffe, Chantal (ed.) (1999): The Challenge of Carl Schmitt. London - New York: Verso.

Mouffe, Chantal (2013): Agonistics: Thinking The World Politically. London - New York: Verso.

Mouffe, Chantal (2018): For a Left Populism. London - New York: Verso.

Mounk, Yasha (2018): The People vs. Democracy. Cambridge, MA: Harvard University Press.

Müller, Jan-Werner (2003): A Dangerous Mind: Carl Schmitt in Post-War European Thought. New Haven: Yale University Press.

Holmes, Stephen (1993): The Anatomy of Antiliberalism. Cambridge/ Massachusetts: Harvard University Press.

Ottmann, Henning (2010): Geschichte des politischen Denkens: Von den Anfängen beiden Griechen bis auf unsere Zeit. Das 20. Jahrhundert: Der Totalitarismus und seine Überwindung. Stuttgart/Weimar: Metzler.

Pikalo, Jernej and Andreja Trdina (2011): Depolitizacija političnega. Primer obravnavanja političnih tem v slovenskih dnevnikih. In: Lukšić, Andrej (ur.). Politološke refleksije. Znanstvena produkcija Centra za kritično politologijo 2009-2010. Ljubljana: FDV, IDV, Center za kritično politologijo, 243-265.

Posavec, Zvonko (1989): Država i političko. Politička misao 26 (1): 22-29.

Rizman, Rudi (2020): Družba in politika v času retrotopije. Teme iz politične sociologije. Ljubljana: Filozofska fakulteta Univerze v Ljubljani.

Robison, Richard (2006): The Neo-Liberal Revolution. Forging the Market State. London: Palgrave Mcmillan.

Stiglitz, Joseph E. (2019): People, Power and Profits. Progressive Capitalism for an Age of Discontent. New York/ London: Allen Lane.

Streeck, Wolfgang (2020): Critical Encounters. Capitalism, Democracy, Ideas. London: Verso.

Streeck, Wolfgang; Armin Schäfer (2013): Politics in the Age of Austerity. Cambridge: Polity Press.

Tozze, Adam (2018): Crashed. How a Decade of Finacal Crisies Changed the World. New York: Viking Press.

Vodovnik, Žiga (2017): Lost in translation. The original meaning of democracy. Teorija in praksa 54 (1): 38-54.

Weiß, Volker (2017): Die autoritäre Revolte. Die Neue Rechte und der Untergang des Abendlandes. Stuttgart: Klett-Cota.

Zielonka, Jan (2018): Counter-Revolution. Liberal Europe in Retreat. Oxford: Oxford University Press. 


\section{SOURCES}

Orban, Viktor (2014): Prime Minister Viktor Orbán's Speech at the 25th Bálványos Summer Free University and Student Camp. Accessible at https://www. kormany.hu/en/the-prime-minister/the-prime-minister-s-speeches/prime-minister-viktor-orban-s-speech-at-the-25th-balvanyos-summer-free-university-andstudent-camp, 16. 3. 2020.

Schmitt, Carl (1922): Politische Theologie. Vier Kapitel zur Lehre von der Souveränität. Berlin: Duncker\&Humblot.

Schmitt, Carl (1932): Der Begriff des Politischen. München: Duncker \& Humblot.

Schmitt, Carl (1938): Der Leviathan in der Staatslehre des Thomas Hobbes: Sinn und Fehlschlag eines politischen Symbols. Hamburg: Hanseatische Verlagsanstalt. 